\title{
Austronesian Language
}

National Cancer Institute

\section{Source}

National Cancer Institute. Austronesian Language. NCI Thesaurus. Code C161901.

A language family that is widely dispersed throughout Maritime Southeast Asia,

Madagascar and the islands of the Pacific Ocean, with a few members in continental Asia. 